\title{
PENDIDIKAN LIFE SKILLS SEBAGAI MODAL SOSIAL (STUDI KASUS DI SD MUHAMMADIYAH CONDONGCATUR YOGYAKARTA)
}

\author{
Agus Firmansyah \\ Studi Islam konsentrasi Kependidikan Islam, Pascasarjana, \\ UIN Sunan Kalijaga Yogyakarta, \\ Email:firmansyabjawari@yahoo.com
}

\section{Abstract}

The aim of this research was to describe life skills education as the social capital that must be possessed by students. This research was a qualitative field study which seekeed to describe the data collected from the field and the literature related to the discussion. The focus of this research was on Condongcatur Muhammadiyah Elementary School. The data collection technique used to obtain data was observation, interviews, and documentation. The data was analysed in stages: data reduction, data presentation and the summarization of research results. The results of this research were as follows: first, the concept of life skills education in SD Muhammadiyah Condongcatur is an integrated system of life skills education. The implementation of life skills education is part of three main components of learning activities, namely intra-curricular, extra-curricular and school programmes and activities. Second, the process of implementing life skills education, shaping social asset at Condongcatur Muhammadiyah Elementary School, through two stages, the implementation of life skills education to build cooperation in school mosques and the application of life skills education to build confidence among students.

Keywords: Lifeskills Education, Social Capital, and Elementary Schools

\section{Abstrak}

Penelitian ini bertujuan untuk mendeskripsikan pendidikan kecakapan hidup (life skills) sebagai modal sosial yang harus dimiliki peserta didik di SD Muhammadiyah Condongcatur. Penelitian ini merupakan penelitian lapangan (field reseach) yang bersifat kualitatif yang berusaha mendeskripsikan data-data yang diperoleh dari lapangan maupun literatur yang berkaitan dengan pembahasan. Fokus penelitian ini adalah SD Muhammadiyah Condongcatur. Untuk mendapatkan data digunakan teknik pengumpulan data melalui observasi, wawancara, dan dokumentasi. Keseluruhan data dianalisis dengan tahapan: mereduksi data, menyajikan data, dan menyimpulkan hasil penelitian. Penelitian ini menyimpulkan, yaitu: pertama, konsep pendidikan kecakapan hidup (life skills) di SD Muhammadiyah Condongcatur berupa konsep pendidikan kecakapan hidup dengan sistem terpadu. Pelaksanaan pendidikan life skills ada pada 3 komponen utama kegiatan pembelajaran yaitu intrakurikuler, ekstrakurikuler, dan program dan kegiatan sekolah. Kedua, proses pelaksanaan pendidikan kecakapan hidup (life skills) membentuk modal sosial di SD Muhammadiyah Condongcatur melalui 2 tahapan yaitu pelaksanaan pendidikan kecakapan hidup (life skills) membangun kerjasama di masjid sekolah dan penerapan pendidikan life skills dalam membangun kepercayaan peserta didik.

Kata Kunci: Pendidikan Lifeskills, Modal Sosial, dan Sekolah Dasar 


\section{Latar Belakang}

Pendidikan merupakan faktor yang dominan dalam pembentukan manusia. Pendidikan yang berkualitas memberikan dampak terbentuknya Sumber daya manusia (SDM) yang berkualitas. Pendidikan yang berkualitas ditentukan oleh dua hal antara lain: sistem pendidikan dan anggaran negara terhadap bidang pendidikan. keberhasilan dua faktor tersebut didukung oleh masyarakat dan keluarga. ${ }^{1}$

Pendidikan berkualitas bagi generasi muda, berguna untuk mewujudkan generasi penerus bangsa yang maju. Salah satu Indikator pendidikan yang berkualitas adalah tidak adanya pembedaan antara hak laki-laki dan perempuan dalam mengakses atau memperoleh pendidikan. Semuanya mempunyai porsi yang sama dan seimbang dalam proses penerimaan ilmu pengetahuan, pembentukan keimanan dan ketaqwaan, dan terwujudnya karakter mulia. $^{2}$

Karakter merupakan internalisasi dan implementasi nilai kebaikan yang ditampilkan dalam bentuk tindakan. Manusia berkarakter adalah manusia yang mampu menghidupkan nilai-nilai kebaikan dalam kehidupan. ${ }^{3}$ Proses pendidikan karakter didukung oleh penanaman nilainilai karakter yang sesuai dengan perkembangan zaman agar tidak terbelakang.

1 Ana Latifah, "Tidak Ada Pembatasan Bagi Wanita Dalam Dunia Pendidikan," https://www.kompasiana.com/analathifah/552073 85a33311114746cef9/tidak-ada-pembatasan-bagiwanita-dalam-dunia-pendidikan, diakses 11 November 2018,

2 Moh Roqib, Pendidikan Perempuan (Yogyakarta: Gama Media, 2003), h. 48.

3 Ngainun Naim, Character Building Optimalisasi Peran Pendidikan Dalam Pengembangan Ilmu Dan Pembentukan Karakter Bangsa (Yogyakarta: ArRuzz, 2012).
Dilain pihak, tantangan dan permasalahan yang dihadapui generasi muda di era global semakin multidimensional. Berbagai macam tuntutan kehidupan, baik berupa kondisi positif ataupun negatif yang datang dari diri mereka sendiri atau bahkan dari masyarakat sekitar. Oleh karena itu, generasi muda bangsa ini diharuskan mempunyai berbagai macam keterampilan hidup, sehingga dapat menjalani kehidupan dengan penuh rasa optimis dan percaya diri guna meraih kesuksesan di masa yang akan datang.

Pendidikan adalah suatu proses rekayasa sistematis untuk meningkatkan kuantitas dan kualitas keterampilan belajar secara holistik. Inti pendidikan adalah memanusiakan manusia, yaitu mengembangkan minat dan bakat manusia secara holistik sehingga mampu menjadi khalifah yang membawa misi rahmatan lil alamin. Berdasarkan inti pendidikan tersebut peserta didik memiliki sikap kritis terhadap realitas dan mampu menjadi solusi permasalahan hidupnya, masyarakat, dan negara. ${ }^{4}$ Pencapaian tujuan tersebut ditunjang dengan pendidikan berbasis kecakapan hidup (life skills). Kecakapan hidup (life skills) bermakna peserta didik berkemampuan keterampilan hidup yang didukung dengan kemampuan dasar. Kemampuan dasar tersebut meliputi membaca, menulis, menghitung, merumuskan, memecahkan masalah, mengolah sumber daya, bekerja dalam tim, terus belajar di tempat kerja, mempergunakan teknologi dan sebagainya. ${ }^{5}$

${ }^{4}$ Sri Sumarmi, "Konsep Dasar Pendidikan Kecakapan Hidup (Life Skill) Dan Relevansinya Dengan Pendidikan Islam," Jurnal Ilmu Pendidikan Islam 4, no. 3 (2002): 171-75.

${ }^{5}$ Departemen Agama RI, Pedoman Integrasi Life Skill Terhadap Pembelajaran Madrasah Aliyah (Jakarta: Derektorat Jenderal Kelembagaan Agama Islam, 2005). 
Penelitian atau jurnal yang membahas tentang tema modal sosial antara lain: pertama, Penelitian Ratna Puspitasari dan Aris yang membahas kurikulum bermuatan modal sosial dalam Pembelajaran IPS di MTS/SMP”. 6 Kemajuan lembaga pendidikan setingkat SMP/ MTs di Kota Cirebon yang maju dan berkualitas unggul disebabkan modal sosial yang terjalin secara kuat diantara 4 komponen tersebut. pendidik merupakan pihak yang bertanggungjawab dalam penurunan kualitas pendidikan. Padahal penurunan kualitas pendidikan disebabkan oleh dampak negative globalisasi. Dampak negatif tersebut adalah penurunan modal sosial dalam lembaga pendidikan di Cirebon. Kedua, penelitian Musa Pelu yang membahas pemanfaatan modal sosial dan modal budaya dalam pendidikan budi pekerti.7" Modal sosial yang digunakan dan dimanfaatkan dalam implementasi pendidikan budi pekerti di SMP Muhammadiyah 5 Surakarta dan SMP Kasatriyan 1 Surakarta meliputi hubungan saling percaya, norma, serta jaringan dan keterkaitan. Modal budaya dalam pelaksanaan pendidikan budi pekerti meliputi sistem budaya, yaitu nilai-nilai budaya Jawa dan nilai-nilai agama. Sistem sosial yaitu budaya sekolah SMP Muhammadiyah 5 Surakarta berbasis budi pekerti dan agama, budaya sekolah SMP Kasatriyan 1 Surakarta berbasis budi pekerti dan multikultural serta kultur komunitas, kebudayaan fisik, yang meliputi kebijakan pendidikan, dan slogan-slogan yang mengandung pesan-pesan moral/nilai-nilai

6 Ratna Puspitasari dan Aris, "Analisa Kurikulum Bermuatan Modal Sosial Dalam Pembelajaran IPS Di MTS/SMP, Edueksos : Jurnal Pendidikan Sosial \& Ekonomi, Vol 8, No 1 (Juni, 2019), h. 72-84.

${ }^{7}$ Musa Pelu, "Pemanfaatan Modal Sosial dan Modal Budaya dalam Pendidikan Budi Pekerti", Jurnal Pembangunan Pendidikan: Fondasi dan Aplikasi, Volume 3, No 2, Desember 2015, h. 198-212 budi pekerti. Jaringan kerjasama yang sinergis dilandasi rasa percaya dan kesamaan nilai norma merupakan modal sosial yang telah dimanfaatkan dan dikelola dalam rangka mendukung pelaksanaan kebijakan kurikulum pendidikan budi pekerti di SMP Muhammadiyah 5 Surakarta dan SMP Kasatriyan 1 Surakarta.

Ketiga, penelitian Marsofiyati dan Susan Febriantina yang menjelaskan pemberdayaan komite sekolah dalam meningkatkan efisiensi pengelolaan sekolah di Kota Depok (studi kasus pada komite SMAIT Al-Qudwah Kota Depok)". ${ }^{8}$ Berdasarkan hasil penelitian dan pembahasan di atas diperoleh kesimpulan bahwa Pemberdayaan komite sekolah di SMAIT Al-Qudwah Kota Depok belum sepenuhnya maksimal. Hal ini ditandai dengan masih terbatasnya ruang pemberdayaan bagi pengurus komite sekolah sebagai mitra sekolah. Di samping itu sekolah juga belum sepenuhnya memfasilitasi komite sekolah untuk menggali potensi kepengurusannya sehingga keberadaannya dapat diberdayakan. Keempat, Penelitian Farida Hanum, Sisca Rahmadonna, dan Yulia Ayriza menjelaskan tentang modal sosial yang dikembangkan guru di sekolah berkualitas di Yogyakarta. ${ }^{9}$ Hasil penelitian menunjukkan bahwa modal sosial yang paling dominan dan banyak digunakan oleh guru di sekolah dengan mutu tinggi adalah mutual trust dan norma/tata tertib. Selain

8 Marsofiyati dan Susan Febriantina, "Pemberdayaan Komite Sekolah Dalam Meningkatkan Efisiensi Pengelolaan Sekolah Di Kota Depok (Studi Kasus Pada Komite Smait AlQudwah Kota Depok)", Econosains: Jurnal Online Ekonomi \& Pendidikan, Vol 14 No 2, Agustus 2016, h. 201-224

9 Farida Hanum, Sisca Rahmadonna, dan Yulia Ayriza, "Modal Sosial Yang Dikembangkan Guru di Sekolah Berkualitas di Yogyakarta", Lurnal Kependidikan: Penelitian Inovasi Pembelajaran, Volume 46, Nomor 2, November 2016, h. 233-245 
itu, guru telah membangun dan mengembangkan networking yang produktif di antara semua warga sekolah. Kelima, Penelitian Ju'subaidi yang menjelaskan tentang Peningkatan Mutu Madrasah melalui Modal Sosial. ${ }^{10}$ Hasil penelitian ini adalah Struktur dan nilai-nilai yang dimiliki masyarakat sekitar sebenarnya merupakan modal sosial yang seharusnya dimanfaatkan oleh madrasah untuk meningkatkan mutu pendidikannya. Modal sosial ini menjadi sarana mencapai tujuan pendidikan nasional.

Pendidikan life skills di SD Muhammadiyah Condongcatur secara hadir dan hidup dalam setiap kegiatan sekolah. Pendidikan Life skills yang dilaksanakan mampu membentuk modal sosial. Modal sosial tersebut yang diharapkan dari SD Muhammadiyah Condongcatur adalah Islami, Cerdas, dan mandiri. Penelitian ini bertujuan untuk mengetahui konsep pendidikan kecakapan hidup (life skills) di SD Muhammadiyah Condongcatur dan proses pendidikan kecakapan hidup (life skills) dalam membentuk modal sosial di SD Muhammadiyah Condongcatur. Penelitian ini merupakan penelitian lapangan (field reseach) yang bersifat kualitatif yang berusaha mendeskripsikan data-data yang diperoleh dari lapangan maupun literatur yang berkaitan dengan pembahasan. Fokus penelitian ini adalah SD Muhammadiyah Condongcatur. Untuk mendapatkan data digunakan teknik pengumpulan data melalui observasi, wawancara, dan dokumentasi. Keseluruhan data di analisis dengan tahapan: mereduksi data, menyajikan data, dan menyimpulkan hasil penelitian.

10 Ju'subaidi, "Peningkatan Mutu Madrasah melalui Modal Sosial", $N A D W A$, Vol 6, No 2 (2012), diakses pada Maret 2020 http://garuda.ristekbrin.go.id/documents/detail/29 $\underline{9074}$
Istilah life skills secara etimologi yang terdiri dari dua kata, yaitu life yang berarti "hidup" dan skill yang berarti "kecakapan, keahlian, keterampilan" 11 Sedangkan tambahan ' $s$ ' menunjukkan jamak yang mempunyai arti banyak atau lebih dari satu. Maka dari itu life skills dapat diartikan sebagai kecakapan hidup.

Menurut pendapat Brolin yang dikutip oleh Musaheri, kecakapan hidup adalah perpaduan antara pengetahuan dan ketrampilan yang dimiliki seorang untuk hidup secara mandiri. ${ }^{12}$ Pendapat tersebut diperkuat dengan tim Broad Based Education Departemen Pendidikan Nasional menjelaskan kecakapan hidup adalah kecakapan yang dimiliki seseorang untuk berani menyelesaikan permasalahan hidup dengan sikap kreatif dan inovatif. ${ }^{13}$ Berdasarkan uraian di atas, dapat disimpulkan kecakapan hidup adalah kecakapan yang dimiliki oleh seseorang untuk dapat hidup di lingkungan masyarakat yang luas berani dan mampu menghadapi problema hidup.

Pengembangan kecakapan hidup (life skills) seseorang dilaksanakan melalui proses pendidikan. Pendidikan adalah proses sistematis yang dilakukan seseorang untuk mempengaruhi dan mengubah perilaku seseorang sesuai cita-cita pendidikan. ${ }^{14}$ Sedangkan berdasarkan UU RI Nomor 20 Tahun 2003 bab 1 Pasal 1 Nomor 1:

Pendidikan adalah usaha sadar dan terencana untuk mewujudkan suasana belajar dan

11 John M. Echols and Hassan Shadily, Kamus Inggris Indonesia (Jakarta: Gramedia, 2003), h. 357.

12 Musaheri, Pengantar Pendidikan (Yogyakarta: IRCiSoD, 2007), h. 216.

${ }^{13}$ Tim Broad Based Education Departemen Pendidikan Nasional, Kecakapan Hidup Melalui Pendekatan Pendidikan Berbasis Luas (Surabaya: Surabaya Intellectual Club (SIC), 2007), h. 9.

14 Chalijah Hasan, Dimensi-Dimensi Psikologi Pendidikan (Surabaya: Al-Ikhlas, 1994), h. 46. 
proses pembelajaran agar peserta didik secara aktif mengembangkan potensi dirinya untuk memiliki kekuatan spiritual keagamaan, pengendalian diri, kepribadian, kecerdasan, akhlak mulia, serta keterampilan yang diperlukan dirinya, masyarakat, bangsa dan negara. ${ }^{15}$

Dari uraian tersebut dapat diartikan bahwa pendidikan adalah suatu proses pembelajaran berupa usaha yang terencana secara sistematis dan tanggungjawab oleh sekelompok orang guna mengembangkan potensi serta kemampuan peserta didik sesuai cita-cita pendidikan nasional. Pendidikan yang berkualitas akan menghasilkan lulusan (output) yang berkualitas pula. ${ }^{16}$ Dengan demikian, pendidikan tidak hanya berlangsung secara formal saja tetapi meliputi keseluruhan kegiatan yang dilakukan peserta didik guna perkembangan kepribadian baik berupa formal, informal, dan non formal. Proses pendidikan tersebut melahirkan konsep pendidikan sepajang masa atau life-long education yang di maknai bahwa pendidikan adalah bagian dari kehidupan itu sendiri. ${ }^{17}$ Karena pendidikan berlangsung sepanjang masa, maka proses pendidikan tersebut berlaku seumur hidup.

Menurut Anwar "kecakapan hidup (life skills) adalah pemberian bekal keterampilan yang praktis dan pragmatis yang dibutuhkan oleh dunia kerja." ${ }^{18}$ Maka

${ }^{15}$ Kementrian Pendidikan dan Kebudayaan Republik Indonesia, "Undang-Undang Sistem Pendidikan Nasional, 2003: UU RI No. 20 Tahun 2003 Bab 1 Pasal 1 Nomor 1," diakses November 12 , 2018 ,

http://hukum.unsrat.ac.id/uu/uu_20_03.htm.

16 Muchlas Samani and Hariyanto, Konsep

Dan Model Pendidikan Karakter (Bandung: Remaja Rosdakarya, 2011), h. 37.

17 Nurani Soyomukti, Teori-Teori Pendidikan (Yogyakarta: Ar-Ruzz, 2010), h. 28.

18 Anwar, Pendidikan Kecakapan Hidup (Life Skill Education) Konsep Dan Aplikasi (Bandung: Alfabeta, 2012), h.22. dari itu pendidikan kecakapan hidup (life skills) adalah pendidikan yang memberikan dan mengajarkan dasar-dasar serta latihanlatihan tentang nilai-nilai kehidupan yang meliputi kecakapan personal, kecakapan sosial, kecakapan intelektual dan kecakapan untuk bekerja, berusaha dan hidup mandiri. Dengan demikian, pendidikan kecakapan hidup (life skills) tidak hanya dibutuhkan guna memperoleh suatu pekerjaan saja tetapi keseluruhan sikap dan keterampilan yang dimiliki seseorang guna menghadapi masalah-masalah dalam hidupnya. Oleh karena itu, pendidikan kecakapan hidup (life skills) sangat dibutuhkan generasi muda dalam menghadapi problematika kehidupan.

Berdasarkan keputusan Departemen Nasional kecakapan hidup (life skills) dikelompokkan menjadi dua, yaitu kecakapan hidup yang bersifat umum (General Life skills) dan kecakapan hidup yang bersifat spesifik (Spesific Life skills). ${ }^{19}$ Kecakapan hidup yang bersifat umum (General Life skills) yaitu keseluruhan kecakapan hidup yang bersifat mendasar serta umum semua orang. Kecakapan ini terbagi dalam tiga domain, yaitu: pertama, kecakapan personal (personal skill) atau (self awareness). Kedua, kecakapan berfikir rasional (thinking skill) ketiga, Kecakapan sosial (social skills).

Kecakapan mengenal diri (personal skill) yaitu kecakapan seseorang untuk memahami sesuatu serta mengaktualisasikan jati dirinya agar bisa menemukan kepribadiannya. Kecakapan mengenal diri terdiri dari tiga bagian antara lain: penghayatan sebagai abdun (hamba kepada Tuhan Yang Maha Esa), bagian dari masyarakat, serta kesadaran diri tentang kelebihan yang kekurangan.

19 Departemen Agama RI, Pedoman Integrasi Life Skill Terbadap Pembelajaran Madrasah Aliyah..., h.8. 
Kecakapan berpikir rasional (thinking skill) adalah kecakapan seseorang untuk memahami sesuatu masalah serta mengaktualisasikan diri berpikir secara rasional. Kecakapan ini mencakup antara lain: kecakapan memperoleh informasi, mengolah informasi, mengambil keputusan serta menyelesaikan permasalahan secara kreatif dan inovatif. Adapun keterampilan personalnya berupa keterampilan pengambilan keputusan dan problem-solving.

Kecakapan sosial atau kecakapan antar personal (interpersonal skills) adalah keterampilan seseorang untuk memahami semua permasalahan yang ada dalam lingkungan masyarakat sekitar serta mampu bergaul dengan semua kalangan masyarakat. Kecakapan ini mencakup antara lain: komunikasi dengan empati, dan bekerja sama. Sedangkan keterampilan sosialnya seperti keterampilan berkomunikasi, pengedalian diri, solusi dan konflik, mampu hidup berdampingan dengan siapapun.

Kecakapan hidup yang bersifat spesifik (Spesific Life skills) adalah kecakapan yang dimiliki seseorang untuk menyelesaikan permasalahan pada bidangbidang tertentu atau kompetensi teknis. Kecakapan ini terdiri dari dua bagian, yaitu: Kecakapan akademik (academic skill) dan kecakapan vokasional (vocational skill)

Kecakapan akademik dikenal dengan kemampuan berfikir ilmiah yang merupakan pengembangan dari kecakapan berfikir rasional yang bersifat umum. Kecakapan akademik mengacu pada kegiatan yang bersifat intelektual. Kecakapan ini terdiri beberapa bagian antara lain: mengidentifikasi variabel dan mampu menjelaskan hubungan antar variabel, merumuskan hipotesis, serta merancang dan melaksanakan penelitian.

Kecakapan vokasional sering disebut dengan kecakapan kejurusan. kecakapan kejurusan adalah kecakapan yang berkaitan dengan bidang market oriented. Bentuk nyata dari kecakapan ini adalah kemampuan seseorang bekerja secara totalitas dipantau atau tidak dipantau. Kecakapan vokasional sesuai untuk peserta didik mengandalkan ketrampilan psikomotorik.

Berdasarkan uraian di atas, dapat disimpulkan bahwa dalam kehidupan sehari-hari terdapat kedua unsur (general life skills dan spesifik life skills) saling berhubungan satu sama lain. Oleh sebab itu, pendidikan kecakapan hidup (life skills) memberikan keterampilan semua kecakapan tersebut secara holistik.

Pendidikan yang berorentasi pada kecakapan hidup, mempunyai tujuan antara lain: pertama, mengaktualisasikan potensi peserta didik secara konsisten sehingga mampu menyelesaikan permasalahan hidup. Kedua, mendesaian pembelajaran supaya fungsional bagi kehidupan peserta didik dalam menghadapi kehidupannya sekarang dan di masa depan. Ketiga, memberikan kesempatan dan otonomi pada lembaga pendidikan untuk mengembangkan pembelajaran yang fleksibel, sesuai dengan pendidikan berbasis luas. Keempat, memberdayakan dan pemanfaatan sumber daya di lingkungan sekolah/sekolah, dan di masyarakat sesuai prinsip manajemen berbasis sekolah. ${ }^{20}$

Berdasarkan tujuan pendidikan yang berorentasi kecakapan hidup di atas, menjelaskan bahwa sekolah diharuskan memberikan tambahan pendidikan yang luas serta berorentasikan dalam kecakapan hidup (life skills). Pendidikan tambahan tersebut bukan hanya dalam lingkup mata pelajarn saja, tetapi sebuah materi yang dapat memotivasi peserta didik agar mempunyai keterampilan sehingga dapat memanfaatkannya di masa depan.

\footnotetext{
${ }^{20}$ Departemen Agama RI..., h.12.
} 
Adapun manfaat pendidikan kecakapan hidup (life skills) terbagi menjadi dua yaitu manfaat secara umum dan manfaat secara khusus. Manfaat secara umum sebagai pemberian bekal keterampilan untuk menyelesaikan permasalahan diri sendiri, masyarakat, dan negara. Adapun manfaat secara khusus dan spesifik antara lain: membekali individu dengan kecakapan, merespon kejadian dalam hidup, memungkinkan hidup dalam masyarakat yang interdependen, membuat individu mandiri, produktif, mengarahkan pada kehidupan yang memuaskan dan memiliki kontribusi pada masyarakat, dan memungkin individu untuk berfungsi secara efektif di dunia yang selalu berubah. ${ }^{21}$

Berdasarkan manfaat yang telah diuraikan di atas, pentingnya pendidikan kecakapan hidup (life skills) dipengaruhi perjalanan hidup tiap individu di zaman modern ini. Tanpa adanya keterampilan, seseorang tidak bisa menjalani kehidupan yang serba modern serta akan selalu merasakan kekhawatiran akan masa depan mereka. Maka dengan pendidikan yang berorentasikan kecakapan hidup (life skills) ini diharapkan mampu mempersiapkan individu-individu yang tangguh serta kuat secara mentalitas dalam menghadapi problematika dalam kehidupan sehari-hari.

Pendidikan life skills merupakan upaya pembentukan modal sosial bagi peserta didik. Menurut Lounry, modal sosial adalah sekumpulan sumber yang terintegrasi dalam keluarga dan organisasi sosial yang bermanfaat untuk perkembangan kognitif dan sosial anakanak dan pemuda. ${ }^{22}$ Bedasarkan pengertian tersebut, Modal sosial memiliki empat kata

${ }^{21}$ Departemen Agama RI..., h.13.

22 James S. Coleman, Foudations of Sosial Theory (Dasar-Dasar Teori Sosial) (Bandung: Nusa Media, 2011), h.415. kunci mendasar antara lain: Sumber, lembaga pendidikan, dan perubahan dan perkembangan kognitif. Sumber yang dimaksud dalam pengertian tersebut seperangkat alat, media, metode yang digunakan oleh keluarga atau lembaga. Lembaga pendidikan yang dimaksud sekolah dan organisasi sosial yang dibentuk. Perkembangan kognitif dan sosial adalah perubahan dan bertambahanya pengetahuan dan rasa kepedulian terhadap sesama. Modal sosial terbagi dalam dua kategori utama yaitu segala elemen yang terdapat dalam struktur sosial dan semua tindakan-tindakan individu yang ada dalam struktur sosial. ${ }^{23}$ Pada hakikatnya lembaga pendidikan merupakan modal sosial. Sekolah terdiri elemen sumber yang berupa modal fisik dan tenaga pendidik, kependidikan, dan siswa meruapakan struktur modal sosial. Modal sosial, pada gilirannya, tercipta ketika relasi antara orang-orang yang mengalami perubahan sesuai dengan cara-cara yang memudahkan tindakan. ${ }^{24}$

James Coleman membagi Modal sosial dalam tiga bentuk antara lain: struktur kewajiban (obligations), ekspektasi, dan kepercayaan. Dari tiga tersebut terdapat dua kunci modal sosial antara lain: kepercayaan dari lingkungan sosial dan perluasan aktual dari kewajiban yang sudah dipenuhi (obligation held). Berdasarkan perspektif tersebut, individu yang tinggal dalam struktur sosial dengan saling kepercayaan tinggi memiliki modal sosial yang lebih baik daripada situasi sebaliknya. Modal sosial bagian selanjutnya adalah jaringan informasi (information channels). Informasi memiliki peranan penting sebagai dasar tindakan. Informasi merupakan suatu yang mahal. Informasi mampu merubah pola pikir dan pola

${ }^{23}$ Coleman..., h. 418.

${ }^{24}$ Coleman..., h. 429 
tindakan individu. Individu yang memiliki jaringan lebih luas akan lebih mudah dan murah untuk memperoleh informasi, sehingga dapat dikatakan modal sosialnya tinggi; demikian pula sebaliknya. Modal sosial bagian selanjutnya adalah norma dan sanksi yang efektif (norms and effective sanctions). Norma merupakan ikatan yang mengikat individu dalam golongan untuk mendapatkan prestasi. Norma yang berlaku secara kuat dan efektif dalam komunitas yang dapat mempengaruhi generasi muda untuk berkreasi, berprestasi dan memanfaatkan waktu sebaik-baiknya (baving a good time).

Menurut Adi Dewanto, dan Rahmania Utari, ${ }^{25}$ Modal sosial meruapakan salah satu bagian dari modal-modal lainnya yang mendukung pendanaan dalam pendidikan dalam tingkat makro maupun mikro. Pemberdayaan modal sosial bukan berarti mengeksploitasi masyarakat sebagai sumber dana utama dalam lembaga pendidikan, melainkan modal sosial memberikan tanggung jawab sekolah untuk senantiasa menggunakan pendanaan dengan efektif dan efisien. Kepala sekolah senantiasa membangun jejaring dengan masyarakat secara holistik dan intens. Jejaring tersebut mampu mendatangkan modal sosial yang berguna bagi perkembangan dan kemajuan sekolah. Berdasarkan hasil penelitain yang tersebut dapat dipertegas bahwa modal sosial memiliki pengaruh yang signifikan dalam pembiayaan sekolah. Beberapa sekolah swasta telah melakukan sistemisasi modal sosial yang tersedia. Sistemisasi modal sosial terutama jaringan dengan masyarakat yang meliputi pengusaha, kepala pemerintahan, kepala desa, kepala dinas,

25 Adi Dewanto and Rahmania Utari, "Pemberdayaan Modal Sosial dalam Manajemen Pembiayaan Sekolah," Journal Ekonomi Dan Pendidikan 3, no. 1 (2005): 25-33. dan jabatan yang terkait mampu meningkatkan sumber pembiayaan sekolah dan kesejahteraan tenaga pendidik dan pendidik.

Modal sosial dapat diintegrasikan dengan modal kultural. Integrasi modal sosial dan modal kultural secara seimbang mampu menciptakan proses pendidikan yang humanis dan religius. Menurut Sopidi, ${ }^{26}$ bahwa proses integrasi modal sosial dan modal kultural dapat mengembangkan nilai-nilai pendidikan karakter di sebuah lembaga pendidikan pesantren. Hasil temuan Sopidi antara lain: pertama, bahawa integrasi modal sosial dan modal kultural di pesantren As-Sakinah Indramayu berprinsip humanis (memanusiakkan). Kedua, modal sosial dan modal kultural dalam pengembangan karatek didasarkan pada pola tauladan atau uswah antara kyai, ustadz, santri. Ketiga dampak integrasi modal sosial dan modal kultural terhadap pemgembangan nilai-nilai karakter santri adanya hubugan vertikal santri berposisi yang di bawah sementara kyai dan ustdaz yang selalu di atas.

Modal sosial memiliki peran signifikan untuk meninjau orientasi individu. Orientasi individu dapat yang berbeda tersebut menunjukkan modal sosial yang dimiliki setiap individu. Modal sosial yang baik mampu membuat orientasi individu visionir, sementara modal sosial yang tidak baik mampu membuat individu pesimis dalam melihat masa depan. Menurut Sumarno, dkk, ${ }^{27}$ bahwa pengembangan orientasi mahasiswanya

\footnotetext{
26 Sopidi, "Integrasi Modal Sosial dan Budaya dalam Pengembangan Nilai-Nilai Pendidikan Karakter Sliyeg Indramayu," Journal Holistic 15, no. 2 (2014): 287-306.

27 Sumarno, Haryanto, and Bambang Saptono, "Orientasi Modal Sosial Dan Modal Cultural Di Faultas Ilmu Pendidikan UNY," Journal Penelitian Ilmu Pendidikan 6, no. 2 (2013): 68-77.
} 
haruslah senantiasa menunju dan berprinsip modal sosial dan modal kulrutal. Dua modal tersebut menjadi alat mahasiswa untuk mendapatkan lapangan kerja dan meningkatkan etos kerja.

\section{Hasil dan Pembahasan}

\section{Konsep Pendidikan Kecakapan Hidup (Life skills) SD Muhammadiyah Condongcatur}

Konsep pendidikan kecakapan hidup (life skills) dalam pembentukan karakter terlihat dari visi SD Muhammadiyah Condongcatur. Visi tersebut adalah Islami, Cerdas, dan Mandiri.

Pendidikan kecakapan hidup (life skills) berarti proses pendidikan yang berlangsung guna mengembangkan, melatih serta menyiapkan peserta didik dalam kecakapan atau keahlian personal agar dapat menghadapi seluruh permasalah hidup tanpa adanya rasa kekhawatiran. Pendidikan tersebut bukan hanya bersifat keahlian bekerja saja (vocational) tetapi seluruh sikap serta keterampilan seseorang dalam menyelesaikan masalah. Pendidikan life skills di SD Muhammadiyah Condongcatur bersifat terpadu dengan berbagai program sekolah baik bersifat intrakurikuler maupun ekstrakuriler.

Berdasarkan buku panduan kurikulum SD muhammadiyah Condongcatur pendidikan kecakapan hidup terdapat dan tersebar di berbagai mata pelajaran antara lain: SBK, HW, dan Show and tell. Dalam SBK terdapat beberapa kegiatan yang berhubungan dengan pendidikan kecakapan hidup seperti ketrampilan membuat kerajinan tangan dari barang bekas seperti kardus, botol minuman aqua, dll. ${ }^{28}$ Mata pelajaran HW terdapat kegiatan yang berhubungan

28 Wawancara dengan guru SBK IS, tanggal 16 April 2018 dengan pendidikan life skills. Adapun beberapa kegiatan dalam HW yang memberikan bekal pendidikan life skills antara lain: memasak, merapikan baju, membersihkan kamar mandi, memasang kancing, dll. ${ }^{29}$ Berdasarkan pengamatan peneliti dan selaku partisipan terdapat beberapa kekurangan dalam pendidikan life skills dalam kegiatan HW. Kelemahan dari pembelajaran HW adalah orang tua yang ikut campur mengubah beberapa kebijakan dengan memberikan masukan pada wali kelas.

Adapun kegiatan-kegiatan intrakurikuler yang bermuatan pendidikan kecakapan hidup terdapat dalam keputrian. Kurikulum keputrian disusun berdasarkan kebutuhan siswa dan praktek kehidupan keseharian. Hal ini diperkuat dengan pendapat Koordinator keputrian yang menjelaskan segala bentuk materi dan keterampilan dalam keputrian disusun berdasarkan kebutuhan siswa dan pemberian keterampilan. ${ }^{30}$ Konsep pendidikan kecakapan hidup di SD Muhammadiyah Condongcatur dengan sistem terpadu. Hal ini diperjelas dengan bagan berikut. Keterpaduan ini terdapat dalam setiap pembelajaran. Pembelajaran mata pelajaran selalu mengandung muatan life skills.

\section{Proses Pelaksanaan Pendidikan Kecakapan Hidup (Life skills) membentuk modal sosial di SD Muhammadiyah Condongcatur}

Berdasarkan analisis yang dilakukan penulis secara insider pada di SD Muhammadiyah Condongcatur. Maka penulis memfokuskan proses pelaksanaan pendidikan kecakapan hidup (life skills) pada

${ }^{29}$ Wawancara dengan koordinator HW DD, tanggal 15 April 2018

30 Wawancara dengan koordinator keputrian TSD, tanggal 20 april 2018 
tiga hal yaitu pelaksanaan pendidikan kecakapan hidup (life skills) di Masjid sekolah, penerapan pendidikan kecakapan hidup (life skills), serta penilaian pendidikan kecakapan hidup (life skills) dalam pembentukan karakter. Adapun uraiannya secara rinci sebagai berikut:

Pelaksanaan Pendidikan Kecakapan Hidup (Life skills) membangun kerjasama antar siswa di Masjid sekolah.

Konsep kepemimpinan (leadership) adalah konsep dasar pendidikan kecakapan hidup (life skills) yang diterapkan guna mendidik serta melatih siswa sebagai calon pemimpin. Adapun uraian kegiatan tersebut antara lain:

\section{Sholat Dhuha Berjamaah}

Sholat dhuha berjamaah dilaksanakan setiap kelas dengan waktu yang berbeda. Siswa diminta untuk menjadi imam serta dibimbing oleh semua guru tiap kelas. Selesai Sholat, salah satu siswa siminta secara bergantian menjadi pemimpin dalam berdoa dan menyiapkan temannya untuk keluar masjid dengan tertib dan tenang. Bahkan sebelum sholat siswa secara bergantian sesuai kelompok kelas menata sepatu dengan tertib di depan masjid.

Adapun komentar dan pendapat peserta didik tentang pembiasaan penataan sepatu sebelum shalat yaitu, menurut AR, "saya suka dengan penataan sepatu karena terlihat rapi dan nyaman". ${ }^{31}$ Menurut ADA, "saya suka penataan sepatu karena sepatunya menjadi rapi". ${ }^{32}$ Menurut MD, "saya suka penataan sepatu sebelum shalat karena saya melakukan kebaikan." 33

31 Wawancara dengan AR kelas 5A tanggal 16 oktober 2018

32 Wawancara dengan ADA kelas 5A tanggal 17 oktober 2018

33 Wawancara dengan MD kelas 5A tanggal 17 oktober 2018
Menurut NPA, "penataan sepatu sebelum shalat bagus sekali karena membuat sepatu agar tidak hilang”. ${ }^{34}$ Menurut ARA, "penataan sepatu sebelum shalat bagus sekali, tetapi merepotkan karena kadang diberantakin oleh kelas lain." ${ }^{35}$

\section{Kultum}

Kultum merupakan kegiatan pemberian nasehat yang dilakukan siswa setelah berdoa pada shalat dhuha. Siswa secara bergantian diminta untuk memberikan nasehat kepada temannya di mimbar. Kegiatan ini berjalan dengan lancar. Bahkan siswa antusias mengikuti kegiatan ini. Adapun beberapa pendapat para siswa tentang kegiatan kultum di sekolah antara lain: "seru, jika tidak siap jadi deg-degan", 36 "saya suka dengan kultum, tetapi perlu adanya materi kultum yang beragam", 37 "dapat banyak materi. Bisa tepuk tangan dan pesannya berfaedah". ${ }^{38}$

\section{Penerapan Pendidikan Kecakapan Hidup (Life skills) membangun kepercayaan}

Pendidikan sebagai salah satu sarana dalam proses pembentukan pribadi seseorang, maka dari itu harus meningkatkan proses pembelajaran dengan baik. Proses tersebut berupa konsep peningkatan kecakapan hidup (life skills) anak dalam ranah psikologi serta kehidupan sosial. Berdasarkan hasil temuan di lapangan dapat disimpulkan bahwa pendidikan yang berorentasikan pada kecakapan hidup (life skills) peserta didik

${ }^{34}$ Wawancara dengan NPA kelas 5A tanggal 20 oktober 2018

35 Wawancara dengan ARA kelas 5A tanggal 21 oktober 2018

36 Wawancara dengan LY kelas 5C tanggal 21 April 2018

37 Wawancara dengan ARL kelas 5C tanggal 21 April 2018

38 Wawancara dengan FTM kelas 5C tanggal 21 April 2018 
mencangkup seluruh aspek kegiatan kepemimpinan. Beberapa kecakapan yang dapat dilatih di lingkungan kelas dan masjid berupa kecakapan memenej waktu, menyelesaikan masalah, serta bersosialisasi dengan teman sebaya. Hal ini bertujuan untuk membekali keterampilan siswa di masa depan. Adapun penerapan pendidikan kecakapan hidup (life skills) terdiri dari kecakapan personal dan kecakapan sosial.

\section{Kecakapan Personal}

Kecakapan personal seseorang berupa proses aktualisasi jati diri tiap individu berupa penghayatan diri sebagai hamba Tuhan Yang Maha Esa, anggota masyarakat dan warga negara, serta mengetahui kekurangan kelebihan diri. Itu semua sudah dijelaskan dalam aturanaturan yang harus ditaati oleh seluruh siswa antara lain: Kewajiban siswa di sekolah dan Larangan bagi Peserta didik.

Kewajiban siswa di sekolah antara lain: pertama, melaksanakan sholat fardhu berjama'ah (Dzuhur dan Ashar) dan tepat waktu. Kedua, melaksanakan amalan sunnah sesuai tuntunan Rasulullah SAW. Ketiga, melaksanakan program 7K (Keamanan, Ketertiban, Kebersihan, Keindahan, Kekeluargaan, Kerindangan, dan Kesehatan), keempat, menggunakan pakaian yang sesuai dengan ketentuan umum di sekolah. Keempat, Bersikap hormat dan sopan santun warga sekolah. Kelima, menjaga nama baik diri, keluarga dan Madrasah. Keenam, lima S (senyum, salam, sapa, sopan, santun)

Adapun Larangan bagi Peserta didik antara lain: pertama, dilarang jajan diluar sekolah. Kedua, dilarang menggunakan alatalat elektronik. Ketiga, dilarang mengambil barang milik orang lain (mencuri)

Berdasarkan uraian di atas, maka dapat disimpulkan bahwa proses penerapan kecakapan personal SD Muhammadiyah Condongcatur mencangkup: penghayatan diri sebagai makhluh Tuhan Yang Maha Esa, anggota masyarakat, serta menyadari akan kelebihan dan kekurangan yang dimiliki. Pelaksanaannya cukup baik walaupun dalam realitasnya belum dilaksanakan secara optimal.

Program harian meliputi berbagai pembiasaan yang diterapkan oleh sekolah untuk membiasakan pengembangan kurikulum PAI berbasis kemandirian. Pembiasaan 6 kebaikan kemandirian di sekolah antara lain: pertama, pembiasaan merapikan sepatu ketika shalat. Kedua, pembiasaan merapikan alat shalat ketika selesai shalat jamaah di sekolah. Ketiga, pembiasaan merapikan buku dan sepatu ketika di perpustakaan. Keempat, pembiasaan merapikan dan membersihkan kelas sebelum pelajaran di mulai. Kelima, Pembiasaan mengembalikan piring dan gelas setelah selesai makan. Keenam, Pembiasaan merapikan kursi setelah pulang sekolah (kursinya diangkat di meja khusus kelas 4-6). Ketujuh, pengecekan buku kegiatan kebaikan kemandirian yang dilakukan wali kelas setelah berdoa pagi hari

\section{Kecakapan Sosial}

Manusia adalah makhluk sosial yang saling tolong menolong antar sesama. Maka kemampuan sosialnya sangat dibutuhkan dalam hal berinteraksi di lingkungan masyarakat sekitar. Adapun kemampuan sosial yang harus dilatih dan ditingkatkan di sekolah adalah kegiatan taawun bencana. Taawun bencana merupakan kegiatan yang pemberian sumbangan kepada siswa yang ditinggal mati oleh salah satu anggota keluarganya. Serta kegiatan seratus kebaikan yang dilaksanakan dalam pembelajaran akhlak. 


\section{Kesimpulan}

Berdasarkan hasil penelitian tersebut ada beberapa kesimpulan tentang pendidikan life skills sebagai modal social di SD Muhammadiyah Condongcatur antara lain: pertama, Konsep pendidian life skills di SD Muhammadiyah Condongcatur menggunakan pola integrated learning dan integrated kurikulum. Integrated learning adalah pembelajaran tentang nilai-nilai life skills terintegrasi dalam setiap mata pelajaran di SD Muhammadiyah Condongcatur. Integrated kurikulum adalah pendidikan life skills terintegrasi dengan segala komponen kurikulum SD Muhammadiyah Condongcatur yang terdiri dari pilar mata pelajaran, ekstrakurikuler, dan program kegiatan sekolah.

Kedua, Pelaksanaan pendidikan life skills di SD Muhammadiyah Condongcatur dapat terlihat dari kegiatan kultum, shalat dhuha, dzuhur, dan ashar secara berjamaah. Kegiatan tersebut dapat membangun kerjasama antar sesama siswa dan kerjasama antara guru dan siswa. Kerjasama terjadi dari proses adzan dan kultum secara bergantian oleh siswa. Pendidikkan life skills mampu meningkatkan rasa kepercayaan siswa dengan siswa yang lain dengan kegiatan keputrian yang besifat kelompok dalam pembuatan keterampilan, peraturan tata tertib sekolah dan dan taawun ketika ada teman yang kesusahan.

\section{Daftar Pustaka}

\section{Buku}

Anwar. Pendidikan Kecakapan Hidup (Life Skill Education) Konsep Dan Aplikasi. (Bandung: Alfabeta, 2012)

Coleman, James S. Foudations of Sosial Theory (Dasar-Dasar Teori Sosial). Bandung: (Nusa Media, 2011)
Departemen Agama RI. Pedoman Integrasi Life Skill Terhadap Pembelajaran Madrasah Aliyah. (Jakarta: Derektorat Jenderal Kelembagaan Agama Islam, 2005)

Musaheri. Pengantar Pendidikan. (Yogyakarta: IRCiSoD, 2007)

Roqib, Moh. Pendidikan Perempuan. (Yogyakarta: Gama Media, 2003)

Samani, Muchlas, and Hariyanto. Konsep Dan Model Pendidikan Karakter. (Bandung: Remaja Rosdakarya, 2011)

Echols, John M., and Hassan Shadily. Kamus Inggris Indonesia. (Jakarta: Gramedia, 2003)

Hasan, Chalijah. Dimensi-Dimensi Psikologi Pendidikan. (Surabaya: Al-Ikhlas, 1994)

Soyomukti, Nurani. Teori-Teori Pendidikan. (Yogyakarta: Ar-Ruzz, 2010)

\section{Jurnal Ilmiah}

Dewanto, Adi, and Rahmania Utari. "Pemberdayaan Modal Sosial dalam Manajemen Pembiayaan Sekolah." Journal Ekonomi Dan Pendidikan 3, no. 1 (2005): 25-33.

Farida Hanum, Sisca Rahmadonna, dan Yulia Ayriza, "Modal Sosial Yang Dikembangkan Guru di Sekolah Berkualitas di Yogyakarta", Lurnal Kependidikan: Penelitian Inovasi Pembelajaran, Volume 46, Nomor 2, November 2016, h. 233-245

Marsofiyati dan Susan Febriantina, "Pemberdayaan Komite Sekolah Dalam Meningkatkan Efisiensi Pengelolaan Sekolah Di Kota Depok (Studi Kasus Pada Komite Smait AlQudwah Kota Depok)", Econosains: Jurnal Online Ekonomi \& Pendidikan, Vol 14 No 2, Agustus 2016, h. 201224

Musa Pelu, "Pemanfaatan Modal Sosial dan Modal Budaya dalam Pendidikan Budi Pekerti”, Jurnal Pembangunan 
Pendidikan: Fondasi dan Aplikasi, Volume 3, No 2, Desember 2015, h. 198-212

Naim, Ngainun. Character Building Optimalisasi Peran Pendidikan Dalam Pengembangan Ilmu Dan Pembentukan Karakter Bangsa. Yogyakarta: Ar-Ruzz, 2012.

Ratna Puspitasari dan Aris, "Analisa Kurikulum Bermuatan Modal Sosial Dalam Pembelajaran IPS Di MTS/SMP, Edueksos: Jurnal Pendidikan Sosial \& Ekonomi, Vol 8, No 1 (Juni, 2019), h. 72-84.

Sopidi. "Integrasi Modal Sosial dan Budaya dalam Pengembangan Nilai-Nilai Pendidikan Karakter Sliyeg Indramayu." Journal Holistic 15, no. 2 (2014): 287-306.

Sumarmi, Sri. "Konsep Dasar Pendidikan Kecakapan Hidup (Life Skill) Dan Relevansinya Dengan Pendidikan Islam." Jurnal Ilmu Pendidikan Islam 4, no. 3 (2002): 171-75.

\section{Database Online}

Sumarno, Haryanto, and Bambang Saptono. "Orientasi Modal Sosial Dan Modal Cultural Di Faultas Ilmu Pendidikan UNY." Journal Penelitian Ilmu Pendidikan 6, no. 2 (2013): 6877.

Latifah, Ana. "Tidak Ada Pembatasan Bagi Wanita Dalam Dunia Pendidikan." Accessed November 11, 2018. https://www.kompasiana.com/anala thifah/55207385a33311114746cef9/t idak-ada-pembatasan-bagi-wanitadalam-dunia-pendidikan.

Tim Broad Based Education Departemen Pendidikan Nasional. Kecakapan Hidup Melalui Pendekatan Pendidikan Berbasis Luas. Surabaya: Surabaya Intellectual Club (SIC), 2007. Vol 6, No 2 (2012), diakses pada Maret http:/ / garuda.ristekbrin.go.id/docu ments/detail/299074

Kementrian Pendidikan dan Kebudayaan Republik Indonesia. "UndangUndang Sistem Pendidikan Nasional, 2003: UU RI No. 20 Tahun 2003 Bab 1 Pasal 1 Nomor 1." Accessed November $\quad 12,2018$. http://hukum.unsrat.ac.id/uu/uu_20 _03.htm.
Ju'subaidi, "Peningkatan Mutu Madrasah

(1)

